\title{
We all stand together
}

\author{
Food systems must be transformed urgently, hunger is on the rise and the targets of SDG2 are off track. But we \\ are moving briskly to pivotal summits in 2021 and World Food Day has a powerful message of hope and solidarity: \\ 'Grow, Nourish, Sustain. Together'.
}

$\mathrm{P}$ re-COVID, the syndemic of undernutrition, obesity and climate change was described as the greatest challenge for human and planetary health in the 21 st century ${ }^{1}$. The number of hungry people in the world has been rising since 2014, following decades of decline; 690 million people are now undernourished and affordable, healthy diets are out of reach for billions ${ }^{2}$. Locust outbreaks in East Africa have placed millions more at risk of food insecurity, and COVID-19-a pandemic inextricably linked in cause and effect to food systems - could push up to 100 million people into extreme poverty ${ }^{3}$. Off-track targets for SDG2, failing food systems, COVID-19 and other global a ffairs can precipitate pessimism - but hopes, not hurts, should shape the future, and in this Editorial we want to focus on some notes of optimism.

Food systems transformation is irrefutably urgent ${ }^{4}$ and the discourse is segueing towards action, with economic and structural costs, political economy, diversity of cultural norms, equity and social justice, and governance and decision support tools identified as priorities for transformative action ${ }^{5}$. The Global Panel on Agriculture and Food Systems for Nutrition's report Future Food Systems: For People, Our Planet, and Prosperity, launched in September, furnishes policy makers with a direct account, derived from evidence, of the practicalities of food system transitions ${ }^{2}$. The report lays out the manoeuvres necessary for politicians, businesses and civil society to ensure that healthy, sustainable diets are made more available, accessible, affordable and desirable. In recent weeks, the Food Systems Summit has distilled its vision into discreet action tracks - access to safe and nutritious food for all, sustainable consumption patterns, nature-positive production at scale, equitable livelihoods and resilience to vulnerabilities, shocks and stresses. Adding to the momentum, the United Nations Special Envoy for the Food Systems Summit, Agnes Kalibata, has announced 60 Food Systems Champions, an impressive group of leaders and influencers to rally communities around the world to engage with the vision of the summit.
The Tokyo Nutrition for Growth (N4G) Summit 2021 convened by the Japanese government, with a focus on nutrition supporting human capital for social and economic development, will seek high-level commitments from a cross-section of stakeholders to tackle malnutrition. These summits are pivotal moments, and to succeed they need the solidarity of science, business, decision makers and civil society. We are briskly moving from the 'why' of food systems transformation, to the 'how' and the 'who'.

October 16th marks the 75th anniversary of World Food Day. The theme of 2020 - 'Grow, Nourish, Sustain. Together' - draws attention to the role of every individual in transforming food systems for healthy, sustainable diets with a message of responsibility, hope and solidarity. High time to celebrate everyday food heroes, including producers in low- and middle-income countries (LMIC).

In this issue, we publish two papers from the Ceres2030 Collection that aim to advance training, support networks and prospects for farmers in LMIC. As the working-age population in LMIC is set to double in the next 35 years, youth engagement in agriculture could support livelihoods, social cohesion, rural development and elevate families and communities from food insecurity. Youth engagement in agriculture is deemed progressive; and yet, Maïga and colleagues conclude that systematic evaluation of employment outcomes following vocational education and skills training in agriculture are lacking in LMIC. Bizikova and colleagues explore the impact that farmers' organizations, such as cooperatives, self-help and women's groups, have on smallholder livelihoods. Farmers' organizations can benefit farmers' income, yield and production, as well as food security and the environment. Additional support systems for capacity building and better access to material resources are key to ensure that marginalized farmers also benefit from farmer organization membership.

Transformation will depend on political will and social engagement, built on the best scientific evidence. In 2019, the EAT-Lancet
Commission made the case for food systems transformation compelling, and the Global Panel have provided policy solutions, grounded in development realities of LMIC. The N4G Summit and Food Systems Summit in 2021 will seek political, donor and business commitments to put human and planetary health at the heart of food systems. World Food Day 2020 draws on the role of civil society in the great transformation - and high-profile voices that speak about food issues, including Sabrina Dhowre Elba and Idris Elba, Marcus Rashford and Henry Dimbleby, must continue to be used to engage civil society.

And yet, does the evidence support such optimism? In this issue of Nature Food, Damerau and colleagues propose a model for how India can transition to achieve nutrition security, reduce health risks and improve environmental sustainability within natural resource constraints. Shepon and colleagues describe how the re-orientation of current aquaculture systems in Bangladesh for nutrition and minimizing environmental impact can support the sustainable development of this burgeoning industry.

Descriptive statistics on global food systems - hunger and malnutrition, degradation of natural resources, power and powerlessness - can make for grim, and repetitive, reading. However, in these uncertain times, momentum is gathering for food systems transformation. The scientific and political nuts and bolts of how to transform are being thrashed out in the run-up to the pivotal summits of 2021. This World Food Day, the message is a powerful one of responsibility, hope and solidarity.

Published online: 14 October 2020 https://doi.org/10.1038/s43016-020-00178-5

References

1. Swinburn, B. A. et al. Lancet 393, 791-846 (2019).

2. Future Food Systems: For People, Our Planet, and Prosperity (The Global Panel on Agriculture and Food Systems for Nutrition, 2020).

3. Mahler, D. G. et al. Updated estimates of the impact of COVID-19 on global poverty. World Bank Blogs (8 June 2020); https:// go.nature.com/36E1gmA

4. Webb, P. et al. Nat. Food https://doi.org/10.1038/s43016-02000161-0 (2020).

5. Béné, C. et al. Nat. Food 1, 457-459 (2020). 